\title{
Discourse of the Post-COVID 19 New Deal in South Korea
}

\author{
Kyong Yoon ${ }^{1}[$
}

Received: 18 December 2020 / Accepted: 24 March 2021 / Published online: 19 April 2021

(c) The Author(s), under exclusive licence to Springer Nature B.V. 2021

\begin{abstract}
In July 2020, the South Korean government announced a 5-year, post-pandemic plan. This purportedly proactive policy aimed to advance digital and green industries to lay the groundwork for the post-pandemic era. This article examines the South Korean government's early proposal of a post-pandemic policy, titled the Korean New Deal, in order to explore how the pandemic crisis may affect the policymakers' envisioning of the post-crisis society. Moreover, the study examines how this early predictive plan may reveal the ways in which the pandemic is utilized for discursive politics. Drawing on the critical discourse analysis of policy documents and news coverage, this article questions how the "old" language of the developmental state is incorporated into the "new" policy. The study also shows how COVID-19's impacts and uncertainties are translated into political discourses.
\end{abstract}

Keywords Korean New Deal · Digital New Deal · Green New Deal · COVID-19 . Developmental state $\cdot$ Bio-nationalism

\section{Introduction}

The devastating year of 2020 tested governments' abilities to cope with natural and social disasters. Some governments effectively controlled the spread and damage of COVID-19 (e.g. Australia, New Zealand and Taiwan), while others seemed to be quite at a loss (e.g. the USA). Each country's experiences with, and lessons from the crisis, may influence the ways in which its government plans post-pandemic national policies. For example, on July 14, 2020, when the world was relentlessly fighting against the novel virus, the South Korean government announced a 5-year, post-pandemic plan. This plan reinforces some of the government's pandemic crisis measures, such as the extensive use of personal data for public and industrial purposes, while proposing several new projects. This purportedly proactive policy, which aims

Kyong Yoon

kyong.yoon@ubc.ca

1 English and Cultural Studies, University of British Columbia Okanagan, 1148 Research Rd,

Kelowna, BC, Canada 
to advance digital and green industries to lay the groundwork for the post-pandemic era, might be one of the earliest "post-pandemic" national policies proposed by any national government [25]. In comparison, other Asian countries were still consulting to establish post-pandemic national plans $[16,55]$.

While many national and local authorities released crisis management plans to support individuals and industries devastated by the pandemic, it seemed hasty to propose predictive post-pandemic national development plans in the uncertain phase of the COVID-19 crisis, during which the handling of the pandemic was a priority. The South Korean government's early planning of post-pandemic phases seemed to be motivated by its relatively successful containment of COVID-19, which contributed to a high public approval rating. As discussed later, the government promoted its infectious disease control system under the name of "K-bangyeok" (literally meaning K-quarantine). For example, in his 3rd anniversary special speech, President Moon emphasized how successful K-bangyeok was and how it enhanced national pride for South Koreans [8].

This article examines the South Korean government's early proposal of a postpandemic policy, titled the Korean New Deal, in order to explore how the pandemic crisis may affect the policymakers' envisioning of the post-crisis society and how this early predictive plan may reveal the ways in which the pandemic is utilized for discursive politics. The Korean New Deal policy documents [e.g. 13], press releases $^{1}$ and the president's speeches ${ }^{2}$ between July and December 2020, along with media coverage and scholarly materials, will be examined. This article adopts the critical discourse analysis method to examine how seemingly neutral language may in fact be political and ideological [38]. This study questions how the postpandemic society is presented in policy discourses. In particular, it explores how the developmental state discourse is incorporated into the New Deal policy. The study also shows that COVID-19's impacts and uncertainties are translated into political discourses through which digital technology-based mobilization is proposed as an urgent agenda to become a "global leader" country [13].

\section{The Korean New Deal}

The Korean New Deal, also promoted as "K-New Deal", aims to invest 160 trillion KRW (equivalent to approximately USD 133 billion as of July 2020) for the next 5 years, for the digital and sustainable transformation of the nation. The policy document defines the Korean New Deal as "a national development strategy to support the country's recovery from the pandemic crisis and lead the global action against structural changes" [13]. As implied in the term "New Deal", the South Korean government promoted the plan as a twenty-first century Korean equivalent to the postDepression New Deal program implemented by the Franklin D. Roosevelt administration in the 1930s [45].

\footnotetext{
1 Available in Korean at https://www.korea.kr/news/pressReleaseList.do

2 Available in English at https://english1.president.go.kr/BriefingSpeeches/Speeches?page=
} 
Introducing this plan to the public, President Moon Jae-in stated that "The Korean New Deal will set the foundation for Korea's next 100 years" [7]. In the main policy document and the president's speeches, the New Deal plan was defined as an initiative for the country's transition to "seondogukga" (a leading nation). The plan was designed "not only to adapt to the structural changes but also to lead the global community in the post-COVID-19 era" [13]. The government promoted this New Deal plan as "a national strategy for a great transformation" and an effort to strengthen the social safety net to cope with economic uncertainties; moreover, the plan includes efforts to transform the country into a "smart", "green" and "safe" country [13]. The New Deal includes three policy pillars-two industrial foci (i.e. digital and green industries) and one welfare focus (i.e. safety net building).

First, the Digital New Deal aims to create 903,000 jobs by investing in and accelerating the digital economy. This requires the investment of 58.2 trillion won (for the next 5 years) to advance the data, network and artificial intelligence (AI) sectors as the core of long-term economic development. Its objectives include fostering industries integrating data, network and AI, digitalizing education infrastructure, facilitating "contactless" industries and economic activities, such as online-based microbusinesses, and digitalizing social overhead capital that refers to capital goods available to the public.

Second, the Green New Deal targets the creation of 659,000 new jobs in the economic sectors related to climate change, including renewable energy and green industries. According to the plan, public facilities, such as schools, will be remodeled as eco-friendly facilities, while the transition to a low-carbon energy-based economy will be accelerated; furthermore, it aims to build 1750 smart, low-pollution factories relying on renewable energy. In so doing, the existing urban space is transformed into the "smart green city".

Third, the New Deal plan includes the enhancement of safety nets and welfare systems as its key component. In addition to the two industrial pillars (Digital and Green New Deals), the plan introduced its support for building social safety nets, especially in the form of training and the provision of subsidies and incentives. For training, a budget of 28.4 trillion KRW is allocated (financial support for businesses and employees in the digital and green sectors and investment in human resourcesincluding training of 100,000 individuals on data industries and 20,000 individuals in green industries). Subsidies would be available for vulnerable, low-income workers searching for a job for 6 months $(500,000 \mathrm{KRW}$ per month; equivalent to 415 USD), while financial incentives would be provided to businesses in information technology sectors to hire short-term interns for up to 6 months $(800,000 \mathrm{KRW}$ per month to be paid for an intern; equivalent to 665 USD).

As shown in Table 1, the investment in the Green New Deal seems larger than that in the Digital New Deal. However, the digital economy is the most foundational component of the policy given its budget allocation and the central role of digital technology in both New Deal plans. In particular, the Green New Deal projects are largely reliant on markets (42.7 out of 73.4 trillion won is funded by industries), in comparison to the Digital New Deal, which will primarily be funded and controlled by the government. In the policy document and press releases, digital technology is presented as the most important driver of the plan. 
Table 1 Overview of the Korean New Deal Plan (2020-2025) (modified from [13])

\section{- Visions}

O A smart country: "From a fast follower to a first-mover economy"

A green country: "From a carbon-dependent to a low-carbon economy"

O A safe country: "From a socially divided to an inclusive society"

\section{- Policies}

$\bigcirc$ Digital New Deal that promotes digital innovation and dynamics in the economy

- Investment of KRW 58.2 trillion (KRW 44.8 trillion from the treasury) to support the creation of 903,000 jobs

$\bigcirc$ Green New Deal that accelerates transition towards a low-carbon and eco-friendly economy

- Investing KRW 73.4 trillion (KRW 42.7 trillion from the treasury) in such areas as green infrastructure and renewable energy to support the creation of 659,000 jobs

Stronger Safety Net that strengthens the basis for a people-centered and inclusive country

- Investing KRW 28.4 trillion (KRW 26.6 trillion from the treasury)to support the creation of 339,000 jobs

\section{- Projects}

Three projects for Digital New Deal

- Data dam

- Smart government

- Smart healthcare

Four projects for both Digital and Green New Deals

- Green and smart schools

- Digital twin-a digital replica of an object that can be used to analyze and predict (e.g., drones and self-driving vehicles)

- Digitalization of social overhead capital

- Smart and green industrial complexes

Three projects for Green New Deal (e.g. Eco-friendly remodelling of facilities)

- Green remodeling to enhance energy efficiency of private sector buildings

- Green energy

- Eco-friendly mobility (e.g. Electric vehicles)

1 trillion KRW=approximately 0.830 billion USD as of July 2020

It is not only the key component of the Digital New Deal but also the key area of the Green New Deal, in which technological innovation for a sustainable economy is crucial. As seen in Table 1, almost all main Korean New Deal projects involve digital technology sectors. Overall, in the Korean New Deal plan, digital and data technology is presented as a major driving force of the post-pandemic economy [33].

On the surface, the South Korean government's proposal preparing for the postpandemic economy seems proactive and forward-looking. However, the Korean New Deal was evaluated with skepticism by some civic organizations, critics and activists [22, 33, 51, 52]. The most common and fundamental criticism was that the Korean New Deal was not a substantially new plan that entails a paradigm shift despite the government's claim. For example, it was argued that the New Deal recycled several previously proposed (pre-pandemic) plans [14, 33]. The critics questioned the relevance of the term "New Deal" in the Korean plan in that it is substantially different from the historical US New Deal policy [33, 52]. In particular, the historical New Deal involved a paradigm shift in economic policy-a transformation from the formerly laissez-faire economy to a government-regulated economy that aimed to enhance the welfare system and labour rights in response to the crisis of the depression; in comparison, the Korean New Deal does neither 
clearly present any "paradigm shift" nor propose the substantial development of a welfare system in response to the global crisis of the pandemic [3, 33, 59].

Moreover, according to some critics, the Korean New Deal is largely business friendly, as it proposes extensive incentives for industries to invest in the target areas and allows an extensive range of personal data to be available for industrial uses [24, 33]. Even the Green New Deal plan focuses more on the provision of opportunities for enterprises rather than on directly addressing the climate crisis. For example, the funds allocated for the development and support of renewable energy are much smaller than those allocated for the research and development of electric and hydrogen energy cars [34]. The critics argued that this "New Deal" is in reality an "old" deal that repackaged the ideology of developmentalism that led to the rapid industrialization of the country over a few decades [33]. Previous administrations' development-oriented economic policies focused on conglomerates (chaebol)-led national economy that relied on export-oriented development strategies $[14,33,58] .^{3}$

The Korean New Deal was also criticized for its lacking of consideration of how to support individuals who would struggle with the rapid transition to digital and data economy during and after the pandemic [24, 33, 52]. The policy presented a promise of job creation without any specific plan about how the rapid transition to a data-based economy would affect the existing labour power (e.g. the reduced jobs in manufacturing industries) and how the traditional industrial sectors and labourers should respond to the transition [52]. The policy emphasizes the number of new jobs rather than what types of jobs would be created and how sustainable they would be. This approach is compared with that of the historical New Deal's core vision, which laid out the democratic promise of a "new deal" for the "forgotten" workers who struggled under devastating labour conditions caused by the depression [52].

Of course, the Korean New Deal proposes building safety nets for those left behind in the digital transformation. However, as shown in Table 1, the proposed safety net primarily refers to newly created jobs and temporary training rather than substantial increases in long-term welfare sources (such as social services, basic incomes and education) [52]. It is unlikely that short-term internships and training can prepare a large number of workers whose employment may become unstable upon the arrival of the data economy. The Korean New Deal's proposed size of training and investment in its welfare pillar (i.e. the safety net building plan) appears to be limited, compared to those in its industrial pillar (i.e. the Digital and Green New Deal plans) [59]. ${ }^{4}$

Overall, while the Korean New Deal ambitiously projects the nation as a future global leader, it is largely oriented toward the developmentalist ideology [33] and

\footnotetext{
${ }^{3}$ Besides the developmentalist ideology behind the policy, the Korean version of new deal did not seem to create extensive job opportunities. For example, while the government anticipated that the digital dam is a main driver of the country's digital transformation through which as many as 390,000 jobs would be created for the next 5 years, $75 \%$ of the expected jobs are short-term works for "data labelling" [33].

4 The construction of safety nets is addressed not only in the original policy documents but also in the president's speeches. However, on most occasions, the safety net plan remains abstract and marginal. Moreover, there are discursive contradictions around the languages; on some occasions, citizens are defined as human "resources", which are transferrable to economic capital [13], while more intimate languages such as "people" and "care" are often used in the president's speeches [7, 8].
} 
the acceleration of digital capitalism, which would reinforce the datafication of social worlds $[42,56]$. While a significant lesson from the pandemic crisis is to rethink the ideology of developmentalism and generate a sustainable economic and political system through state-citizen alliance [32, 34], the Korean New Deal does not seem to sufficiently engage with such fundamental issues. In fact, the New Deal was announced without adequate consultation and collaboration with civic organizations and public discussions [33]. In particular, the Green New Deal, which seemingly targets urgent and fundamental environmental issues, was included in the Korean New Deal plan at the last minute [34]. While the term "transformation" was used frequently in the policy documents and the president's speeches, the way the New Deal was planned and proposed was far from transformative. The New Deal policy implies the government's desire for the rapid expansion of digital industries without its substantial commitment to sustainable and democratic transformation of the state. Thus, the New Deal reveals contradictions between digital initiatives and environmental policies (i.e. between digital and green policies) [36].

\section{“Digital Transformation" in Post-pandemic Worlds}

As digital technology and industries are at the core of the Korean New Deal, it is important to examine the Digital New Deal plan in further detail by focusing on its emphasis on the data economy. The Digital New Deal's major project is to build a data economy through a national "data dam" (presented as the first project in Table 1).

The data dam is a central platform for collecting and economizing an extensive amount of data. As proposed by the South Korean government, the data dam project can be compared to the construction of the massive concrete Hoover Dam built during the Great Depression (1931-1936), which contributed to creating numerous job opportunities and economic recovery [45]. According to the policy document [13], the data dam refers to a "large collection of data to support big data development" and promotes "a data-driven economy including the collection, standardization, processing and combining of data, and ultimately secures a competitive advantage for the country by creating new industries and accelerating the digital transition of key industries". The data dam project is not only at the core of the Digital New Deal but also symbolizes the focus of the whole Korean New Deal policy - the data economy as the central realm of "digital transformation" [13]. The policy document clearly presents the advancement of data-related industries as the core area of the policy by emphasizing the importance of collecting, disclosing, utilizing and distributing data.

Aiming to build a central control tower, the government proposes that enterprises and corporations participate in the construction of the data dam. For this purpose, the government provides incentives, such as tax cuts for those that invest in data dam-related sectors. According to this plan, the government and corporations would exchange and process various data to generate high-quality services from which citizens can benefit; the data dam would function as a national platform where data are collected and saved [13]. 
The data dam project reveals that the techno-solutionism-an emphasis on digital technology as a solution to the existing or forthcoming crises $[48,49]$ - is central in the Korean New Deal. This is not surprising given the recent South Korean governments' support of the technology sector. They have developed digital infrastructure and, as a result, achieved some fruitful results, as proven by the country's high rank in various technology indicators, such as International Telecommunication Union (ITU)'s Global ICT Development Index, which has continuously ranked South Korea as one of top three leading countries for a decade in terms of access, use and skills of ICTs (Information and Communication Technologies). The discourse of technology as a solution to economic turmoil was evident in the Kim Dae-Jung administration (1998-2003), which took office during the Asian financial crisis. The Kim administration emphasized the ICT sector as a key sector for economic recovery and growth and thus accelerated the introduction of broadband and mobile telecommunication infrastructure [18].

While investments in and attention to the ICT sector are not new for South Korean governments, the specific emphasis on the data economy is a relatively new component of the technology policy discourse. The Moon administration introduced the data economy as a core area of its economy policy since the end of 2017 and proposed a strategy for advancing data industries in 2018, when President Moon announced the "transition to the data economy" [6]. In this speech, Moon notes that the data economy will bring an inevitable global change, and thus "we must have a strategy to engage with the global change". He urged the need for extensive deregulation, in which various types of data, including anonymized personal data, are used for industrial and public purposes. The emphasis on data as an economic sector was in fact presented during the pre-pandemic period when the government launched the AI National Strategy in 2019. This strategy, from which the Digital New Deal and the data dam plan emerged, urged a "paradigm shift" to stimulate the economy and solve various social problems in response to global uncertainty [47]. In the AI National Strategy, the government announced that South Korea should compete with other countries that take initiative to develop AI industries.

Moreover, even prior to the pandemic, the government made a significant effort to deregulate third-party access to personal data. In response to the government's urge for legislation allowing for extensive industrial and public uses of data, the Korean National Assembly passed amendments to the three major data privacy laws in January 2020: the Personal Information Protection Act, the Act on the Promotion of Information and Communications Network Utilization and Information Protection and the Act on the Use and Protection of Credit Information. The amendments included the use of personal data without the individual's consent on certain occasions [21].

This model of the data-driven economy appears to reinforce the extensive use of digital technologies and big data, which is considered to be the main technique behind South Korea's early handling of COVID-19. South Korea was among those countries that extensively utilized contact tracing and data collection measures for preventing and containing the virus. Individuals' digital footprints and 
data were extensively collected, analyzed and shared for tracing and predicting the paths of the virus, which entailed human rights concerns $[28,58]$. The topdown digital surveillance system, which was accompanied by other measures such as fast testing and a relatively affordable public healthcare system, may be maintained on the basis of the public's desire to measure the pandemic in datafied form by identifying and tracing the enigmatic virus through countable and measurable form [32].

The data dam project, which aimed to build a top-down system of all forms of information and data, seems problematic as it reinforces the already highly centralized cybersecurity system and is against the decentralized collection of personal data that is recommended by data rights experts [50]. Moreover, civic organizations criticized the data dam and digital laws for their potential to allow for the extensive commodification of personal information [20, 51]. Indeed, the aforementioned amendments to data privacy laws allow personal information, without the subject's consent once pseudonymized, to be collected, sold, shared and used for the purpose of improvement of big data and AI industries [51].

In the proposed Digital New Deal, data seems to be defined primarily as a means to generate economic profits rather than a commons for community and civil society. The data dam project vividly shows that "data is now a form of capital" in that it is "both valuable and value creating" [53]. Extensive top-down quantification may reaffirm existing social biases, while disguising uncertainty as data, often falsely equated to fact $[39,56]$. The "digital transformation" proposed in the Korean New Deal is not transformative in that it does not substantially move beyond the temporary pandemic measures in which data-driven control was introduced and utilized for government and industries. As observed in the data dam plan, the New Deal's digital transformation draws on the model of central control rather than enabling alternative approaches to development, which is more caring, inclusive and convivial for post-pandemic transformation [32].

\section{Discursive Politics of the Post-pandemic New Deal}

The discourse of digital and data economy, presented in the Korean New Deal, has ideological effects through which a particular worldview is naturalized while others are marginalized. By proposing the 5-year policy in July 2020, at the height of foreign news media's praise for South Koreans' powerful containment of COVID-19, the government might have hoped to maximize its discursive effects. As theorists of discourse argue, discourse justifies and produces knowledge by constructing "the ways in which a topic will be understood, and its repetition across multiple representational texts and within varied institutional contexts consolidates our understanding" [23]. It should also be noted that dominant discourse functions to naturalize certain meanings, while silencing others [4]. Indeed, considering the context, the New Deal discourse may imply several interwoven ideological effects. Among those effects, two seem salient and suggestive 
for understanding how the South Korean state reconstructs its economy and mobilizes its population.

First, technological solutionism [48,49] is implied as a core ideology in the digital transformation of the country. The Moon administration's early announcement of the post-pandemic Korean New Deal may have been motivated by a high public approval rating earned partly as a result of the administration's timely crisis management. In particular, as its rapid and centralized data surveillance earned the South Korean government global attention [40], the government may have aimed to reinforce its assumed role as a solutionist through the post-pandemic New Deal. Indeed, by proposing a post-pandemic national policy earlier than most other countries, the South Korean government might have hoped to present itself as a potential global leader. In his critique of the pervasive application of digital technology during the pandemic, media critic Morozov anticipated two strands of solutionism that are likely to be adopted by governments in the post-pandemic worlds-progressive solutionists believing that timely exposure to the right information through technology can encourage people to behave in the public interest or "punitive solutionists" using data-based surveillance systems to force normalized life patterns and to punish any transgressions [49]. Among the two possible paths, South Korea seems to engage with the progressive solutionist path; however, once the centralized data dam is actualized, it would be likely that data could be used to police sociopolitical dissents (i.e. the punitive solutionist state). The discursive politics of the post-COVID-19 digital economy in South Korea seems to reinforce data technology as an instrument for a new phase of development-as a solution to forthcoming external risks (e.g. the pandemic and global economic recess) and in so doing hides existing problems (e.g. the government's ineffective economic policies, as shown in spikes in housing price).

Second, the policy's data economy discourse appears to be predicated on a neoliberal mode of globalization, in which fierce competition between countries and between individuals on a global scale is considered to be inevitable, and thus, an entrepreneurial mindset is required for survival. On many occasions, the government emphasized that the New Deal plan would be the opportunity to make the country a global leader. For example, the policy document urges taking "a competitive advantage for the country by creating new industries and accelerating the digital transition of key industries" [13]. On many occasions during the campaign for the policy, President Moon Jae-In also used phrases that expressed a desire to advance the country's economy in neoliberal, global markets, such as "becoming a world-leading nation" [8]. This objective to become an advanced country (seonjinguk) is not new for South Koreans, as similar slogans and discourses have recurred over the past several decades, regardless of the political stands of the government. As shown in J. Kim's analysis of the South Korean government documents for the past few decades, the dominant discourse of "developing the country to become an advanced country" has served to justify the governments' introduction of new policies and to extensively mobilize the citizens [26]. Even far before the pandemic, the dominant discourse of national development forced South Koreans to prepare for (imagined) crises [9, 26]. The 
goal of catching up with advanced capitalist countries has been one of the powerful ideologies of the Korean developmental state, which mobilized its people as kukmin (i.e. members of the nation, who are not necessarily individual citizens in civil society but rather are hailed as a collective identifying itself with the nation-state) [9]. ${ }^{5}$

The Korean New Deal had initial discursive effects; it attracted substantial media attention from national newspapers, which frequently addressed it as a news item, primarily in their economy and politics sections. However, news media's responses to the plan were not fully approving, as critics and journalists expressed mixed views on the feasibility and effects of the plan [3,14]. Some argued that the plan did not critically engage with the transformation of the existing economic and political systems but instead projected promises and responses to external problems [3, 33]. The lack of consultation and reflection on existing structural problems was criticized both by conservative and liberal critics [3, 10, 14, 35, 43]. According to liberal and leftist critics, the Korean New Deal discourse does not sufficiently address internal problems, such as the conglomerates (chaebol) - friendly industrial structure that has caused numerous side effects and an insufficient welfare system [33, 59]. In comparison, conservative critics claimed that the New Deal plan drew on the state-led, old-style leadership model and did not introduce extensive deregulation, through which the country's labour market can become far more flexible for an effective response to post-pandemic global capitalism [10].

With its seemingly transformative agenda and rhetoric, the Korean New Deal's discursive politics may obscure domestic conflicts and tensions while proposing that the country become a global leader based upon the confidence acquired during its early pandemic handling. The policy discourse emphasized that South Koreans had to cope with the external crisis caused by the pandemic, including global economic uncertainty. However, ironically, the discourse did not address global agendas and plans for collaborations. In reality, South Korea's socio-political atmosphere during the pandemic was affected by nationalist ideology against adjacent countries and South Korean "exceptionalism" that distinguished itself from other countries, such as Japan, in terms of responses to COVID-19 [58]. Even though acknowledging that the Korean New Deal plan aims at recovery of the national economy in the post-pandemic world, the theme of global collaboration is nearly absent in the Korean New Deal discourse. For example, when compared with North American or European green policies proposed a decade ago, the Korean Green

\footnotetext{
5 Despite variations and diversity within the developmental state model, South Korea has been under the continued influence of the national ideology of developmentalism. The country has often been addressed as an example of the Asian developmental state. With some variations, South Korea has been overall defined as a developmental state in that the government has strategically managed available material resources for maximizing the national economy and accelerating development[4]. The model of the developmental state has been applied to the South Korean contexts of late development and rapid social mobilization drawing on nationalism [57]. According to the developmental state theory, the South Korean government has operated symbiotically with family-owned conglomerates (chaebol), which have served as instruments for managed industrialization and export-led growth. While the ideology of growth-oriented developmentalism was evident during the authoritarian regimes between the 1960s and the 1980 s, it has continued during civic governments that have sought a revised version of developmentoriented state (also referred to as "developmental liberalism") [5].
} 
New Deal plan is substantially lacking in its consideration of global cooperation for sustainable worlds [34].

The ideology of an export-oriented, developmental state, which is observed in the discourse around the Korean New Deal, was already noticed in the government's diligent promotion of its pandemic responses under the branding of K-bangyeok (K-quarantine). For example, the South Korean government offered some developing countries, such as Paraguay, a total of $\$ 53$ million for COVID-19-related assistance $[2,44]$, while globally promoting the K-bangyeok. However, the government's international promotion of the K-bangyeok model did not necessarily involve extensive global collaboration to cope with the pandemic. The K-bangyeok discourse utilized such rhetoric as the "exportation" of South Korea's advanced knowledge and skills, in which its national pride and advancement are strongly implied [46]. In so doing, the discourse disseminated a form of "biopolitical nationalism" that emphasizes the unique national characteristics and measures that may have contributed to the relatively effective containment of COVID-19 [12, 27, 58]. The government's endeavor to export and promote the K-bangyeok model indicates how the global crisis is utilized and signified, especially for national politics. ${ }^{6}$

Indeed, the early announcement of the post-pandemic Korean New Deal would not be sufficiently explained without considering the country's domestic political contexts. Most of all, the post-pandemic New Deal may have been proposed early to reinforce the momentum that the Moon administration earned through its praised responses to COVID-19. Prior to the COVID-19 crisis, despite its promotional slogans and keywords such as "Innovation Economy", the Moon administration, entering its 4th year out of a 5-year term, was not fully successful in its implementation of nationwide reform especially in the economic sector [29,58]. For the first 3 years, the Moon administration generated several economic policies, such as the Incomeled Growth and Innovative Growth policies, proposed under the broad theme of "people-centred economy", which did not turn out to be visibly successful given any economic indicators [1]. The Income-led Growth policy aims to mitigate income polarization by raising minimum wages and increase social resources for low- and

\footnotetext{
${ }^{6}$ Of course, it may not only be the government but also oppositional parties that used the COVID-19 crisis for their own political gains. In the early period of the pandemic, conservative opposition parties, including the conservative United Future Party (the currently renamed People Power Party), criticized the government's safety measures, while urging the government to close the national borders so that inbound travellers from China could be banned. The conservative opposition parties accused the government of not closing the Korea-China border due to its fear of China's power. The call for the immediate closure of border with China resonated with the general publics' opinion as several opinion polls revealed that over $50 \%$ of the survey samples supported Korea-China border closure [60]. However, in the early period of the COVID-19 outbreak, liberal newspapers noted that the opposition parties' criticism of the government's allowance of travellers from China was not necessarily supported by scientific evidence but was instead reliant on the political rhetoric in which Chinese people and other foreigners are equated with COVID-19 [15].

The politicization of the COVID-19 crisis has continued until a later phase of the pandemic. In the end of 2020 and early 2021, when several countries announced their vaccine rollout schedule, it turned out that the South Korean government did not have pre-purchase agreements with the two major vaccine providers Pfizer and Moderna. Opposition parties and conservative news media harshly criticized the government for its insufficient preparation in building a diversified vaccine portfolio. For example, a conservative newspaper's editorial lamented that South Korea was far behind many other countries in terms of vaccine rollout [11].
} 
middle-income individuals, while the Innovative Growth policy focuses on government support for new businesses, startups and small- and medium-sized enterprises (SMEs) in order to respond to the so-called fourth industrial revolution [1]. Paradoxically, the COVID-19 crisis functioned to divert the public's attention from the unsuccessful economic reform to the external threat of the pandemic, to some extent [58]. In so doing, the government-led nationalist responses to the external threat rapidly emerged. To continue the momentum, the government might have needed a discursive instrument to effectively mobilize the citizens. In this regards, the Korean New Deal, which signifies a national goal and pride ("Korea") and a new vision ("New Deal"), can be considered a form of discursive politics.

Of course, the New Deal policy is not only ideological but also involves action plans for economic recovery. Export-oriented economies, such as South Korea, would be relatively vulnerable to the prolonged pandemic and thus urgently need an aggressive economic recovery plan [25]. However, it is undeniable that the pandemic and the post-pandemic policies in South Korea had discursive effects that served to mobilize the citizens toward the nationalist and developmental state. As Yi and Lee argued, South Korea "demonstrated a highly nationalist and politicized model of pandemic containment, linking a country's pandemic to its global status and to the ruling party's political agenda" [58]. This argument can be applied, at least partly, to the discourse around the post-pandemic Korean New Deal. The policy appeared to operate as a discursive politics through which the top-down, development-oriented and nationalist model of post-crisis economic recovery is justified. The purportedly proactive, yet hasty, proposal of the Korean New Deal does not seem to offer transformative imagination and strategies needed for exploring (post)pandemic citizenship through which people can explore civic deliberation for a democratic and sustainable society.

\section{Conclusion}

The Korean New Deal has brought about anticipation and concern. As one of the earliest post-pandemic national policies, the Korean New Deal plan attracted domestic and international media attention [31]. Some reports positively evaluated the plan [25], which can be "a case study for new national policies in the post-COVID worlds" [25]. In comparison, others were relatively critical of the plan's lack of progressive objectives or novelty [33, 37]. Despite extensive media coverage and the president's continued endorsement, this ambitious policy did not receive sufficient attention from the general public because the COVID-19 crisis was prolonged and became far more serious after the announcement of this policy in the spring of 2020. In August 2020, South Korea encountered the second wave of COVID-19 cases, while confronting the third wave in December 2020. In particular, the number of COVID-19 positive cases spiked to around 1000 per day in December 2020 from around 100 daily cases in October. The sudden increase overwhelmed the national health system [41]. On December 12, President Moon apologized for his administration's failure to handle the latest wave of COVID-19 [19]. Later in December, South Korea witnessed an increasing number of COVID-19-caused deaths, some of which occurred due to the lack of available 
hospital beds. On December 29, 2020, South Korea recorded 40 daily COVID-19 deaths, which is the largest number since the outbreak in early 2020 [17].

As reviewed in this article, the Korean New Deal aimed to take the initiative to become a world-leading nation in the post-pandemic world. However, despite the proposal's ambition, the New Deal does not sufficiently articulate its vision for global changes during and after the pandemic. Rather, the proposal reads as an extension of the recurring nationalist discourse of competitive race to development and global recognition, which has been exercised by the consecutive governments and policymakers for the past several decades [26]. The developmental state ideology may also have been exercised in the country's highly centralized control and management of the COVID-19 crisis [40, 58]. In response to the pandemic, the South Korean government disseminated the discourse of bio-nationalism to become a world-leading nation. This discourse of nationalism-driven, top-down management of crises appeared to be incorporated into the New Deal plan. The plan seems to rework the ideology of the developmental state, which may serve to mobilize its people under (imagined) external threats.

South Korea's recurring discourse of the developmental state affected the ways in which the government handled the pandemic and planned the post-pandemic national policy. The Moon administration often revealed its rhetoric of becoming a worldleading nation by effectively overcoming the pandemic crisis and proactively exploring the new area of the digital economy. This is evident in the very first part of the New Deal plan; the government sought to redefine the country as the "first mover" in the digital economy, shifting away from its self-defined, existing position as a "fast follower" in the global economy [13]. The government's ambition to be a leading nation in post-pandemic worlds was presented in relative terms-in competition with other economically advanced countries. This discourse implies that the post-pandemic social vision proposed by the South Korean government might be drawn from the old model of the developmental state that mobilized its people toward an exportoriented, competitive race to become a world-leading nation [33].

What would the post-COVID world look like? South Korea's COVID-19 "exceptionalism", by which the country's effective risk management was highly praised in the early months of the pandemic, has increasingly been challenged. The Moon administration's earlier, self-identification as "No 1. Country" in COVID-19 handling [8], which paved the way for the ambitious Korean New Deal, was overshadowed by spikes in positive cases and death later in 2020. The "failure" in Korean exceptionalism may paradoxically tell us what is missing in the country's post-pandemic policies - the vision of sustainable development that can be advanced and maintained through civic participation rather than top-down, nationalist and developmentalist rush to be a world-leading nation. The discourse around the Korean New Deal reveals how the old ideology of the developmental state is integrated into the new language of post-pandemic visions. The paradox of the Korean New Deal's discursive politics calls for further discussions about the transition to sustainable post-pandemic worlds.

Data Availability Not applicable. 
Code Availability (Software Application or Custom Code) Not applicable.

\section{Declarations}

Conflict of interest The author declares no conflict of interest.

\section{References}

1. Ahn, C. Y. (2019). Beware the law of unintended consequences: Why South Korea's Income-led Growth Policy isn't working. Global Asia, 14(3), 64-77. Retrieved November 1, 2020, from https:// www.globalasia.org/v14no3/feature/beware-the-law-of-unintended-consequences-why-southkoreas-income-led-growth-policy-isnt-working_choong-yong-ahn

2. Bae, H. (2020). S. Korea to provide $\$ 53 \mathrm{~m}$ to Latin America in coronavirus-related ODA. Korea Herald. Retrieved December 3, 2020, from http://www.koreaherald.com/view.php?ud=2020051800 0705

3. Bang, J. H. (2020, July 17). The Korean New Deal, without a deal. Hankyoreh 21, 1322. Retrieved from January 18, 2021, from http://h21.hani.co.kr/arti/economy/economy_general/48971.html

4. Beltrán, M. (2018). Representation. In Kackman, M., \& Kearney, M. C. (Eds.). The craft of criticism: Critical media studies in practice (pp. 97-108). London: Routledge.

5. Chang, K. S. (2010). South Korea under compressed modernity: Familial political economy in transition. London: Routledge.

6. Cheongwadae (2018). Deregulation for data economy. Retrieved December 5, 2020, from https:// www1.president.go.kr/articles/4122

7. Cheongwadae (2020a). Keynote address by President Moon Jae-in at presentation of Korean New Deal initiative. Retrieved December 5, 2020, from https://english1.president.go.kr/BriefingSp eeches/Speeches/852

8. Cheongwadae (2020b). Special address by President Moon Jae-in to mark three years in office. Retrieved December 5, 2020, from http://english1.president.go.kr/BriefingSpeeches/Speeches/820

9. Cho Han, H. (2000). "You are entrapped in an imaginary well": The formation of subjectivity within compressed development-a feminist critique of modernity and Korean culture. Inter-Asia Cultural Studies, 1(1), 49-69.

10. Cho, H. S., \& Im, S. B. (2020). Hiring 190 million by investing 160 Trillion KRW: The Korean New Deal lacks in "how". Joongang Ilbo. Retrieved December 1, 2020, from https://news.joins.com/artic le/23824674

11. Chosun Ilbo. (2021, February 25). Editorial: The 102nd vaccination in the world, Is Korea such a country? Chosun Ilbo. Retrieved March 15, 2021, from https://www.chosun.com/opinion/editorial/ 2021/02/25/CWIHT7CQ7VG5RHL5AE5PJEUNOI

12. de Kloet, J., Lin, J. \& Chow, Y. F. (2020). 'We are doing better': Biopolitical nationalism and the COVID-19 virus in East Asia. European Journal of Cultural Studies, 23(4), 635-640. https://doi. org/10.1177/1367549420928092

13. Government of Republic of Korea (2020). Korean new deal: National strategy for a great transformation. Retrieved October 15, 2020, from https://english.moef.go.kr/pc/selectTbPressCenterDtl.do? boardCd=N0001\&seq $=4948$

14. Han, S. C. (2020). The Korean New Deal, why it is criticized as the "Old Deal”. Hankook Kyungjae. Retrieved December 3, 2020, from https://www.hankyung.com/opinion/article/2020071947741

15. Hurh, N. S. (2020). 'Why not banning inbound travellers from China?' The conservative oppositional parties fomenting fear and hatred. Kyunghyang Shinmin. Retrieved March 15, 2021, from http://news.khan.co.kr/kh_news/khan_art_view.html?art_id=202001282212005

16. Inkster, I. (2020). Taiwan's post-pandemic window. Taipei Times. Retrieved December 20, 2020, from https://www.taipeitimes.com/News/editorials/archives/2020/12/11/20037485062020/12/11/ 2003748506

17. Jeon, J. Y., \& Kim, S. M. (2020, December 21). 14 deaths while waiting: Some intensive care units may even have to be emptied for COVID-10 patients. Donga Ilbo. Retrieved March 16, 2021, from https://www.donga.com/news/Society/article/all/20201221/104562611/1 
18. Jin, D. Y. (2005). Socioeconomic implications of broadband services: Information economy in Korea. Information, Communication \& Society, 8(4), 503-523.

19. Jung, J. Y. (2020). President Moon, apologies and appeal, but still uncertain. Hankook Ilbo. Retrieved January 1, 2020, from https://www.hankookilbo.com/News/Read/A20201213174100 02972

20. Jung, S. J. (2020, July 21). The Digital New Deal that accommodates corporations' needs at the expense of information rights. Yonhap News. Retrieved November 15, 2020, from. https://www.yna. co.kr/view/AKR20200721078300004

21. Kang, D. H. (2020). The revised three data laws' key areas and prospects. 2020 KISA (Korea Internet \& Security Agency) Report, 2, 14-19.

22. Kang, S. D. (2020). The Korean New Deal and disaster capitalism. Retrieved December 10, 2020, from http://greenreview.co.kr/greenreview_article/2683

23. Kidd, J. (2016). Representation. London: Routledge.

24. Kim, B. K. (2020) The Moon administration's 'New Deal' is not different from the Park administration's 'Creative Economy'. OhmyNews. Retrieved November 1, 2020, from http://www.ohmynews. com/NWS_Web/View/at_pg.aspx?CNTN_CD=A0002667385

25. Kim, D. (2020). South Korea's 'New Deal': Seoul is already looking ahead to the post-COVID world. Diplomat. Retrieved December 1, 2020, from https://thediplomat.com/2020/07/south-koreasnew-deal2020/07/south-koreas-new-deal

26. Kim, J. (2018). Eurocentrism and development in Korea. London: Routledge.

27. Kim, J. H. (2020). Competition for global bio-hegemony and South Korea: Issues that K-bangyeok model fails to address. Asian Regional Review: DiverseAsia, 3(2), 1-6. Retrieved March 1, 2021, from http://diverseasia.snu.ac.kr/?p=4245

28. Kim, J. S. (2020). Information rights swept by the wave of the 'new normal'. Hankyoreh. Retrieved December 1, 2020, from http://www.hani.co.kr/arti/science/issue/950338.html

29. Kim, K. P. (2020). Democratizing the economy: Moon Jae-In's policy on the Korean economy. Economy and Society, 126, 278-301.

31. Kirk. D. (2020, July 14). Korea reveals 'New Deal' designed to boost jobs, revive sagging economy. Forbes. Retrieved November 3, 2020, from https://www.forbes.com/sites/donaldkirk/2020/07/14/ koreas-reveals-new-deal-designed-to-boost-jobs-revive-sagging-economy/?sh=23dc 84803250

32. Leach, M., MacGregor, H., Scoones, I., \& Wilkinson, A. (2021). Post-pandemic transformations: How and why COVID-19 requires us to rethink development. World Development, 138. Retrieved March 10, 2021, from https://doi.org/10.1016/j.worlddev.2020.105233

33. Lee, K. S. (2020, August 6). The Korean New Deal, planned in haste: Substantially revise it, centring on the Green New Deal. Kyunghyang Shinmun. Retrieved November 3, 2020, from http://m. biz.khan.co.kr/view.html?art_id=202008062019005

34. Lee, J. H., \& Woo, J. (2020). Green New Deal policy of South Korea: Policy innovation for a sustainability transition. Sustainability, 12(23), 10191. https://doi.org/10.3390/su122310191

35. Lee, M., \& Choi, H. (2020, October 26). President Moon's Korean New Deal: $75 \%$ of the plan is the "recycled" of older plans. Chosun Ilbo. Retrieved December 1, 2020, from https://biz.chosun.com/ site/data/html_dir/2020/10/26/2020102602075.html

36. Lucivero, F. (2020). Big data, big waste? A reflection on the environmental sustainability of big data initiatives. Science and engineering ethics, 26(2), 1009-1030.

37. Macdonald, S. (2020). How green is South Korea's Green New Deal? Diplomat. Retrieved December 1, 2020, from https://thediplomat.com/2020/08/how-green-is-south-koreas-green-new-deal

38. Machin, D., \& Mayr, A. (2012). Critical discourse studies: A multimodal approach. London: Sage.

39. Madianou, M. (2020). A Second-order disaster? Digital technologies during the COVID-19 pandemic. Social Media+ Society, 6(3). https://doi.org/10.1177/2056305120948168

40. Martin, T. W., \& Yoon, D. (2020). How South Korea successfully managed coronavirus. Wall Street Journal. Retrieved January 15, 2021, from https://www.wsj.com/articles/lessons-from-south-koreaon-how-to-manage-covid-11601044329

41. McCurry, J. (2020). South Korea: from early Covid success to fears over 'ferocious spread of virus'. Guardian. Retrieved January 10, 2021, from https:/www.theguardian.com/world/2020/dec/15/ south-korea-how-early-covid-competence-gave-way-to-a-second-wave2020/dec/15/south-koreahow-early-covid-competence-gave-way-to-a-second-wave

42. Milan, S. (2020). Techno-solutionism and the standard human in the making of the COVID-19 pandemic. Big Data \& Society, 7(2). https://doi.org/10.1177/2053951720966781 
43. Min, J. Y. (2020, October 14). The Korean New Deal as a panacea: From overcoming the COVID19 to balanced national development. Hankook Ilbo. Retrieved December 10, 2021, from https:// www.hankookilbo.com/News/Read/A2020101314460005201

44. Ministry of Culture, Sports and Tourism (2020a). The government giving Central and South American countries 53 million dollars to support their response to COVID-19: Promotion of K-bangyeok. Retrieved March 1, 2021, from https://www.korea.kr/news/policyNewsView.do?newsId=14887 2488

45. Ministry of Culture, Sports and Tourism (2020b). The Korean New Deal. Retrieved March 1, 2021, from https://www.korea.kr/special/policyCurationView.do?newsId=148874860

46. Ministry of Culture, Sports and Tourism (2020c). K-bangyeok is in evolution: Towards being a global standard beyond being an exemplary model. Retrieved March 1, 2021, from https://www. korea.kr/news/policyNewsView.do?newsId=148873423

47. Ministry of Science and ICT (2019). Press release: Announcement of the AI national strategy. Retrieved March 1, 2021, from https://www.korea.kr/news/pressReleaseView.do?newsId=15636 6736

48. Morozov, E (2013). To save everything, click here: The folly of technological solutionism. London: Public Affairs.

49. Morozov, E. (2020, April 15). The tech 'solutions' for coronavirus take the surveillance state to the next level. Guardian. Retrieved October 10, 2020,from https://www.theguardian.com/commentisf ree/2020/apr/15/tech-coronavirus-surveilance-state-digital-disrupt

50. Naudé, W., \& Vinuesa, R. (2020). Data, global development, and COVID-19. WIDER Working Paper 2020/109. Retrieved December 1, 2020, https://www.wider.unu.edu/sites/default/files/Publi cations/Working-paper/PDF/wp2020-109.pdf

51. Oh, B. (2020). It's not a digital new deal, but a digital waste of time. Monthly Trends in Welfare, 263, 29-35

52. Park, Y. (2020). The Korean New Deal without the consideration of labour. Monthly Trends in Welfare, $263,24-28$

53. Sadowski, J. (2020). Too smart: How digital capitalism is extracting data, controlling our lives, and taking over the world. Cambridge, MA: MIT Press.

55. Takenaka, H. (2020, July 31). Japan's post-pandemic information technology challenges. Japan Times. Retrieved December 1, 2020, from https://www.japantimes.co.jp/opinion/2020/07/31/comme ntary/japan-commentary/japans-post-pandemic-information-technology-challenges

56. Taylor, L. (2020). The price of certainty: How the politics of pandemic data demand an ethics of care. Big Data \& Society, 7(2). https://doi.org/10.1177/2053951720942539

57. Woo-Cumings (1999). Introduction: Chalmers Johnson and the politics of nationalism and development. In Woo-Cumings, M. (Ed.), The developmental state (pp. 1-31). Ithaca, NY: Cornell University Press

58. Yi, J., \& Lee, W. (2020). Pandemic nationalism in South Korea. Society, 57(4), 446-451

59. Yoon, H. (2020). Absence of the welfare state in the Korean New Deal. Monthly Trends in Welfare, 263, 5-11

60. YTN (2020, March 2). An opinion poll on inbound travellers from China. YTN News. Retrieved November 1, 2020, from https://www.ytn.co.kr/_ln/0103_202003021402341171

Publisher's Note Springer Nature remains neutral with regard to jurisdictional claims in published maps and institutional affiliations. 